\title{
RĘKOPISY WIERSZY KAJETANA KOŹMIANA W ZBIORACH BIBLIOTEKI NAUKOWEJ PAU I PAN W KRAKOWIE
}

Słowa kluczowe: Koźmian Kajetan (1771-1856), rękopisy autorskie poezji, Biblioteka Naukowa PAU i PAN w Krakowie rękopisy

Zbiory rękopiśmienne Biblioteki Naukowej PAU i PAN w Krakowie stanowią cenne źródło dla badaczy dziejów kultury polskiej - historyków, literaturoznawców i teatrologów. Dobry przykład to rękopisy autorskie oraz odpisy rękopiśmienne i maszynowe utworów polskich poetów i dramatopisarzy ${ }^{1}$. Wśród rękopisów można znaleźć bardzo bogatą spuściznę poety Kajetana Koźmiana (1771-1856). Szczególną wartością historyczną i kulturoznawczą cechują się autorskie zapisy rękopiśmienne dzieł twórcy².

${ }^{1}$ Zob. przykłady publikacji nt. rękopisów autorskich, należących do zasobu krakowskiej biblioteki, w tym ich edycji naukowych: P. Żbikowski, Nieznane wiersze Kajetana Koźmiana, [w:] Miscellanea z doby Oświecenia, t. 6, red. Z. Goliński, Archiwum Literackie, t. 25, Wrocław 1982, s. 361-399; A. Uljasz, Rękopisy autorskie dwóch patriotycznych wierszy Jana Lechonia, „Rocznik Biblioteki Naukowej PAU i PAN w Krakowie”, R. 63: 2018, s. 319-332. Przykłady publikacji o odpisach rękopiśmiennych i maszynowych: A. Uljasz, Patriotyczny prolog Zdzisława Kleszczyńskiego dla teatrów warszawskich na 3 maja 1916 r., „Rocznik Biblioteki Naukowej PAU i PAN w Krakowie", R. 61: 2016, s. 147-159; idem, Libretto Ludwika Osińskiego do opery Józefa Elsnera Andromeda z 1807 r. w zbiorach rękopiśmiennych Biblioteki Naukowej PAU i PAN w Krakowie, „Rocznik Biblioteki Naukowej PAU i PAN w Krakowie”, R. 62: 2017, s. 79-103.

${ }^{2}$ Zob. Biblioteka Naukowa PAU i PAN w Krakowie (dalej: Bibl. Nauk. PAU i PAN), rękopis o sygnaturze 2052 (dalej: rkps 2052 i analogicznie przy opisach innych rękopisów ze zbiorów biblioteki). Utwory poetyckie Kajetana Koźmiana oraz wiersze różnych autorów dedykowane Kajetanowi Koźmianowi (168 kart, w tym zapisanych dwustronnie); rkps 2053. Kajetan Koźmian. Utwory poetyckie. Autografy i odpisy (246 kart, w tym zapisanych dwustronnie); rkps 2054. Kajetan Koźmian: Ziemiaństwo polskie, drobne utwory poetyckie i fragment korespondencji z lat 1823-1824 (250 kart, w tym zapisanych dwustronnie). Zob. też Biblioteka Polskiej Akademii Nauk w Krakowie. Katalog rękopisów. Sygnatury 1811-2148, oprac. Z. Jabłoński, A. Preissner, Wrocław-Warszawa-Kraków 1962, s. 177-186. 
Artykuł dotyczy wybranych rękopisów autorskich poezji Koźmiana, dostępnych w Bibliotece Naukowej PAU i PAN w Krakowie. Materiał badawczy jest częścią ${ }^{3}$ bardzo obszernej kolekcji autografów poety i odpisów jego twórczości ${ }^{4}$. $\mathrm{Na}$ końcu dodano aneks - publikację wiersza Koźmiana Kantata na koronacje Napoleona za autografem autora, nieogłoszonego dotąd w opracowaniu naukowym, podpisanego w rękopisie inicjałami imienia i nazwiska - K.K. Utwór ma za temat koronację Napoleona Bonaparte 5 na „cesarza Francuzów” z 1804 r.

Autor wiersza, Kajetan Koźmian, urodził się w 1771 r. we wsi Gałęzów, położonej na terenie powiatu Urzędów w województwie lubelskim, w parafii Bychawa. Jego ojcem był sędzia ziemski Andrzej Koźmian. Koźmianowie nosili herb szlachecki Nałęcz. Przyszły poeta odebrał edukację szkolną w Lublinie oraz Zamościu. Od 1787 do 1792 r. uczył się zawodu adwokackiego w Lublinie, pełniąc funkcję dependenta w kancelariach adwokackich. W Lublinie podjął pierwsze próby twórczości poetyckiej ${ }^{6}$.

Jego najwcześniejsze publikacje to przekłady łacińskich poezji Tibulla oraz Horacjusza, opublikowane w czasopiśmie „Nowy Pamiętnik Warszawski”, wychodzącym w latach 1802-1805. Popularność zyskał wierszami swojego autorstwa, które powstały w okresie Księstwa Warszawskiego, po zwycięstwie Napoleona w wojnie z Austrią. Były to ody na cześć Napoleona. Pierwsza z nich, Oda na zawieszenie ortów napoleońskich w Lublinie, datowana na 1809 r., cieszyła się szczególnie dużą poczytnością. Najbardziej znane dzieło w bogatym dorobku poetyckim Kajetana Koźmiana to poemat Ziemiaństwo polskie. Najstarsza edycja utworu ukazała się w 1830 r. w Puławach na Lubelszczyźnie7.

Kajetan Koźmian jako poeta należy do nurtu literatury nazywanego klasycyzmem postanisławowskim, datowanego na okres od trzeciego rozbioru Polski do końca trzeciego dziesięciolecia XIX wieku'

${ }^{3}$ Bibl. Nauk. PAU i PAN, rkps 2052..., k. 149, 149v, 150, 150v, 151, 151v, 152, 152v, 153, $154,165,166 \mathrm{v}, 168$.

${ }^{4}$ Zob. przypis 2.

5 Bibl. Nauk. PAU i PAN, rkps 2052, k. 154.

${ }^{6}$ E.A. [E. Aleksandrowska], Koźmian Kajetan 1771-1856, [w:] Dawni pisarze polscy od poczatków piśmiennictwa do Młodej Polski. Przewodnik biograficzny i bibliograficzny, t. 2: I-Me, Warszawa 2001, s. 230-231; Z. Żydanowicz, Koźmian Kajetan, [w:] Polski słownik biograficzny (dalej: PSB), t. 15, Wrocław-Warszawa-Kraków 1970, s. 56. Poeta obszernie pisał o swych związkach z ziemią lubelską i zamojską w pamiętnikach, zob. K. Koźmian, Pamiętniki, przedm. A. Kopacz, wstęp oraz komentarz J. Willaume, wstęp edytorski, ustalenie tekstu w oparciu o autograf oraz komentarz filologiczny M. Kaczmarek i K. Pecold, t. 1, Wrocław-Warszawa-KrakówGdańsk 1972, s. 52 i nast. Zob. też I. Chrzanowski, Kajetan Koźmian 1771-1856, [w:] Album biograficzne zastużonych Polaków i Polek wieku XIX, wydane pod kierunkiem komitetu redakcyjnego, który składają Sz. Aszkenazy, B. Chlebowski, S. Dickstein et al., t. 1 z przedm. S. Krzemińskiego, Warszawa 1901, s. 316-318.

7 E.A. [E. Aleksandrowska], op. cit., s. 231-232.

8 Zob. P. Żbikowski, Klasycyzm postanisławowski. Doktryna estetyczno-literacka, Warszawa 1984, s. 42, 63-65, 103-104, 169-270, 272-280, 283, 285, 292-296, 302, 309, 319, 349-351, 353-355; idem, Klasycyzm postanistawowski. Zarys problematyki, Warszawa 1999, s. 32-34, 
Koźmian zasłynął też z recenzji teatralnych. Publikował je w 1816 i 1817 r. jako członek warszawskiego Towarzystwa Iksów na łamach periodyków „Gazeta Warszawska” oraz „Korespondent Warszawski i Zagraniczny”.

Uczestniczył w polskim życiu naukowym, należąc do warszawskiego Towarzystwa Przyjaciół Nauk. W 1811 r. został członkiem korespondentem, zaś w 1812 członkiem czynnym ${ }^{10}$.

Poeta łączył uprawianie twórczości literackiej i publicystycznej z działalnością polityczną. Wchodził w skład regionalnych lubelskich władz powstania kościuszkowskiego jako sekretarz w Komisji Porządkowej w Lublinie. W czasach Księstwa Warszawskiego zajmował urząd zastępcy przewodniczącego komisji okręgu lubelskiego - od 1809 r. W następnym roku awansował do władz centralnych Księstwa na stanowisko referendarza w Radzie Stanu. Po upadku Napoleona zmienił orientację polityczną z polskiej patriotycznej na skrajnie lojalistyczną wobec caratu. Zrobił dużą karierę we władzach Królestwa Polskiego. Był m.in. członkiem Komisji Rządowej Wyznań Religijnych i Oświecenia Publicznego, zwyczajnym radcą stanu, dyrektorem generalnym w Wydziale Administracji Ogólnej Komisji Rządowej Spraw Wewnętrznych i Policji. Przez pół roku, w okresie od maja do października 1827 r., pełnił obowiązki ministra spraw wewnętrznych. W 1829 r. został senatorem-kasztelanem w Senacie. W latach 1830-1831 zajął negatywne stanowisko wobec powstania listopadowego. Po upadku powstańczego zrywu porzucił działalność polityczną i zamieszkał w rodzinnym majątku Piotrowice na Lubelszczyźnie. Skupił się wyłącznie na twórczości poetyckiej, publicystycznej oraz pisaniu pamiętników. Zmarł w Piotrowicach w 1856 r., w wieku 85 lat $^{11}$.

50-52, 54-55, 77, 155-157, 249-261, 268-269, 284-298, 306-307, 308, 336-339; R. Przybylski, Klasycyzm, czyli prawdziwy koniec Królestwa Polskiego, Gdańsk 1996, s. 117-118, 145-146, 278, 313-354, 427, 431.

${ }^{9}$ E.A. [E. Aleksandrowska], op. cit., s. 231.

${ }_{10}$ Ibidem, s. 230; Z. Żydanowicz, op. cit., s. 56.

${ }^{11}$ E.A. [E. Aleksandrowska], op. cit., s. 230-233; Z. Żydanowicz, op. cit., s. 56-58. Powyżej została przedstawiona syntetyczna informacja na temat biografii K. Koźmiana. Bardziej szczegółowe wiadomości czytelnicy znajdą w przywołanych wyżej publikacjach oraz m.in. w następujących opracowaniach naukowych i popularyzatorskich: F.M. [F. Dzierżykraj Morawski], Życie Kajetana Koźmiana, Poznań 1856; J. Willaume, Kajetan Koźmian w świetle nowszych badań, „Annales UMCS. Sektio F Humaniora", vol. 31, 1976, s. 87-101; P. Żbikowski, Kajetan Koźmian. Szkic do portretu, Rzeszów 1991, s. 7-34; Ł. Zabielski, , Uwiędte listki na spróchniatym drzewie”. Starość Kajetana Koźmiana, [w:] idem, Kajetan Koźmian spoza kanonu. Studia i szkice historycznoliterackie, Białystok 2018, s. 199-254. Zob. też opracowania dotyczące twórczości K. Koźmiana: L. Siemieński, Kajetan Koźmian, [w:] Portrety literackie, przez L. Siemieńskiego, Poznań 1865, s. 333-369; J.S. Bystroń, Kajetan Koźmian, [w:] Literaci i grafomani z czasów Królestwa Polskiego 1815-1831, Lwów-Warszawa 1938, s. 79-99; P. Żbikowski, Kajetan Koźmian. Szkic do portretu..., s. 35-46; idem, Ody napoleońskie Kajetana Koźmiana jako panegiryk, „Prace Humanistyczne”, R. 4: 1975, s. 101-154; S. Treugutt, Ody napoleońskie Kajetana Koźmiana, [w:] Geniusz wydziedziczony. Studia romantyczne i napoleońskie, red. M. Prussak, Warszawa 1993, s. 35-93; S. Kufel, Ostatni na „Parnasie”. O Kajetanie Koźmianie - twórcy wyalienowanym, [w:] Od Koźmiana do 
Synem poety był ziemianin i polityk Andrzej Edward Koźmian (1804-1864), autor pamiętników ${ }^{12}$. Syn Andrzeja i zarazem wnuk Kajetana to reżyser teatralny Stanisław Koźmian (1836-1922). Stanisław Koźmian w latach sześćdziesiątych XIX w. był kierownikiem artystycznym teatru miejskiego w Krakowie, a w latach 1871-1885 dyrektorem tej sceny ${ }^{13}$.

Wśród autorskich rękopisów wierszy Kajetana Koźmiana zwracają uwagę ręczne zapisy wierszy dedykowanych wieszczowi narodowemu - poecie i dramatopisarzowi Zygmuntowi Krasińskiemu (1812-1859). Jeden z tych utworów jest zatytułowany w rękopisie Do Z.K., a w druku: Do Zygmunta Krasińskiego. Powstał w okresie 1830-1856. Zaczyna się od strofy „Nie chciej przenikłym docierać wzrokiem”. Poeta deklaruje religijność. Pisze o konieczności ufności w Boga, zdania się na jego łaskę. Według niego trzeba wierzyć, że Bóg będzie sprzyjać ludzkiej pomyślności. Wypowiada to m.in. w dwóch kolejno następujących po sobie czterowersowych zwrotkach: „Odwieczną świata tego Ustawą/ Złe z dobrem idzie koleją/ Na co się próżną dręczyć Obawą/ Lepiej zasypiać z Nadzieja/ Czyli ten wulkan co żarem tleje/ Sam się w wnętrznościach wypali/ Czy Świat pożerczą lawą zaleje/ Miej ufność - Bóg nas ocali"14. Ostatni wers, zawierający deklarację wiary w ocalenie dzięki opatrzności Bożej, można potraktować

Czernika. Studia i szkice o literaturze polskiej XIX i XX wieku, red. S. Kryński, Rzeszów 1992, s. 7-25. Życie i twórczość K. Koźmiana mają za temat publikacje: K. Wojciechowski, Kajetan Koźmian. Życie i dzieła, „Roczniki Towarzystwa Przyjaciół Nauk Poznańskiego”, t. 23, 1896, s. 47-280 (publikacja książkowa tej samej rozprawy: idem, Kajetan Koźmian. Życie i dzieła, Lwów 1897); Kajetan Koźmian (1771-1856). Życie i dzieło, oprac. H. Galle, [w:] Wiek XIX. Sto lat myśli polskiej. Życiorysy, streszczenia, wyjatki, red. B. Chlebowski, G. Korbut, S. Krzemiński, t. II, Kraków 1907, s. 28-38, 57-79; P. Żbikowski, Kajetan Koźmian (1771-1856), [w:] Pisarze polskiego oświecenia, t. 3, red. T. Kostkiewiczowa i Z. Goliński, Warszawa 1966, s. 415-445; idem, Kajetan Koźmian, t. I: Poeta i obywatel (1797-1814), Wrocław-Warszawa-Kraków-Gdańsk 1972; T. Kizwalter, Ludzie i idee Oświecenia w Polsce porozbiorowej, Warszawa 1987, s. 97-108 (rozdział pt. Piewca uroków ziemiańskiego życia, poświęcony Kajetanowi Koźmianowi i jego poematowi Ziemiaństwo polskie). W celu głębszego poznania biografii K. Koźmiana konieczne jest zapoznanie się z wydawnictwem źródłowym - pełną edycją pamiętników poety, publicysty i polityka. Zob. K. Koźmian, Pamiętniki..., t. 1, 2, 3, Wrocław-Warszawa-Kraków-Gdańsk 1972.

12 Zob. Wspomnienia Andrzeja Edwarda Koźmiana, t. 1, Poznań 1867, t. 2, Poznań 1867. Zob. też J. Zdrada, Koźmian Andrzej Edward (1804-1864), [w:] PSB, t. 15, s. 50-53, zob. też ten sam biogram w internetowej wersji PSB, https://www.ipsb.nina.gov.pl/a/ biografia/andrzej-edward-kozmian (dostęp: 29.11.2019).

13 Stownik biograficzny teatru polskiego, t. I: 1765-1965, red. Z. Raszewski, M. Wosiek, K. Zawadzka, H. Garlińska-Zembrzuska, Warszawa 1973, s. 328-330 (hasło Koźmian Stanisław). Zob. też. Stanisław Koźmian, oprac. A. Tytkowska, http://www.encyklopediateatru.pl/osoby/ 60467/stanislaw-kozmian (dostęp: 29.11.2019).

${ }^{14}$ Bibl. Nauk. PAU i PAN, rkps 2052, k. 149. Zob. też K. Koźmian, Do Zygmunta Krasińskiego. Wiersz I, [w:] idem, Różne wiersze, w Krakowie 1881, s. [148] (pełny tekst wiersza - na s. [148]-150), s. II-III (spis treści, zawierający informację o okresie, w jakim powstały m.in. cztery wiersze K. Koźmiana Do Zygmunta Krasińskiego); idem, Do Zygmunta Krasińskiego. Wiersz I, [w:] idem, Wybór poezji, Kraków 2002, s. 83 (pełny tekst wiersza na s. 83-85) (edycja wyboru wierszy K. Koźmiana w serii „Klasyka Mniej Znana”). W cytatach z wiersza Koźmiana - oryginalna pisownia z przywoływanego rękopisu autorskiego. 
jako aluzję do polskich dążeń niepodległościowych, tym bardziej, że dalej autor pisze: „Jużeśmy przeszli przez srogie kary”"15 oraz informuje o tradycji udziału reprezentantów rodu Krasińskich w bohaterskich walkach, w tym w bitwie z Turkami pod Barem w 1674 r. pod wodzą Jana III Sobieskiego i w odsieczy wiedeńskiej z 1683 r. Nazywa Krasińskiego jeszcze za życia wieszczem, składając w ten sposób hołd jego poezji. Podkreśla znacznie niższą wartość własnej twórczości niż dorobku Krasińskiego, pisząc w zakończeniu utworu: „Śmiej się lecz przebacz wiersz rymoklety/ Co Cię uwielbia y kocha"'16.

Kajetan Koźmian był z Zygmuntem Krasińskim w serdecznych przyjacielskich stosunkach i przesyłał mu do lektury swoją twórczość poetycką, o czym świadczy część listów Z. Krasińskiego do K. Koźmiana ${ }^{17}$.

Inny utwór poety ma za adresata ojca wieszcza - generała Wincentego hrabiego Krasińskiego (1752-1858). Tytuł zawiera informację o dacie: Do Wincentego Krasińskiego $w$ roku $1843^{18}$. W drukowanym wyborze poezji Koźmiana z $1881 \mathrm{r}$. jest znacząca różnica między tytułem utworu w druku a jego wersją w rękopisie autorskim. Nazwisko adresata uzupełniono stopniem wojskowym: Do Jenerała Wincentego Krasińskiego w roku $1843^{19}$. Autor wiersza uznał za największy powód Krasińskiego do chwały udział w wojnach napoleońskich. Wbrew rzeczywistości historycznej i zarazem zgodnie z deklaracjami generała przypisuje mu uczestnictwo, a nawet rolę przywódczą w bitwie pod Somosierrą z 1808 r. Informuje czytelników o swej przyjaźni z Krasińskim, m.in. zwracając się do niego: „drogi” („Twa Przyjaźń krzepi mnie drogi Korwinie”) ${ }^{20}$.

Przy lekturze rękopisu i edycji drukowanej zwraca uwagę fakt, że autor już w pierwszych słowach wiersza podkreśla stałość oraz prawość charakteru adresata: „Mąż prawy z Zmianą Doli się nie mieni/ Wie co zaszczyca czoło Co rumieni/ Wśród Igrzysk Losu - gdy ma Duszę stała/ Wychodzi z Chwałą"21. Znaczące jest, że poeta i polityk, który zmienił poglądy z polskich patriotycznych oraz pronapoleońskich na skrajnie ugodowe wobec carskiego zaborcy, dostrzega

${ }^{15}$ Bibl. Nauk. PAU i PAN, rkps 2052, k. 149.

${ }^{16}$ Ibidem, k. 149 (oryginalna pisownia z rękopisu poety).

17 Zob. Z. Krasiński, Listy do Koźmianów, oprac. i wstępem opatrzył Z. Sudolski, Warszawa 1977, s. 21-30, 33-36, 40-53, 639, 709-718. Zob. też M. Rolle, Krasiński i Koźmian, „Gazeta Lwowska” 1912, nr 168, s. 5 [cz. 1 artykułu], „Gazeta Lwowska” 1912, nr 169, s. 5 [cz. 2 artykułu].

18 Bibl. Nauk. PAU i PAN, rkps 2052, k. 165.

${ }^{19}$ K. Koźmian, Do Jenerała Wincentego Krasińskiego w roku 1843, [w:] idem, Różne wiersze..., s. [128].

${ }^{20}$ Bibl. Nauk. PAU i PAN, rkps 2052, k. 165; K. Koźmian, Do Jenerała Wincentego Krasińskiego..., s. [128]. Zob. też S. Kieniewicz, Krasiński Wincenty (1782-1858), [w:] PSB, t. 15, s. 195-198, zob. też ten sam biogram w internetowej wersji PSB, https://www.ipsb.nina.gov.pl/a/ biografia/wincenty-krasinski (dostęp: 28.11.2019).

${ }^{21}$ Bibl. Nauk. PAU i PAN, rkps 2052, k. 165 (oryginalna pisownia z rękopisu autorskiego, ale poeta zapisał w autografie słowa „nie mieni” razem, a nie osobno). Zob. też ten sam fragment w druku, z uwspółcześnioną ortografią: K. Koźmian, Do Jenerała Wincentego Krasińskiego..., s. [128]. 
stałość i konsekwencję u wojskowego, który przeszedł taką samą ewolucję postawy politycznej. Wincenty Krasiński, dawny generał napoleoński, kontynuował karierę wojskową po 1815 r. w wojsku rosyjskim. W 1830 r. dowodził częścią walk przeciwko polskim oddziałom powstańczym ${ }^{22}$. Pochwały ze strony Koźmiana były bardzo mało wiarygodne, tym bardziej, że przypisywał przyjacielowi zasługi w bitwie pod Somosierra.

Inny autorski rękopis Koźmiana to zapis wiersza Anakreontyk do S. Małachowskiego ${ }^{23}$. Tekst został opublikowany po raz pierwszy w 1982 r. przez badacza biografii i twórczości Koźmiana - wybitnego historyka literatury Piotra Żbikowskiego (1935-2011), wraz z innymi niedrukowanymi wcześniej wierszami poety. Żbikowski był związany zawodowo z Wyższą Szkołą Pedagogiczną w Rzeszowie i Uniwersytetem Rzeszowskim (obecna forma organizacyjna i nazwa dawnej WSP). Przywołany wiersz zamieścił w artykule naukowym pt. Nieznane wiersze Kajetana Koźmiana. W tytule wiersza zmienił skrót imienia bohatera - na Anakreontyk do St. Małachowskiego. W tej samej publikacji ogłosił też liczne inne inedita z twórczości poety, w większości z zasobu Biblioteki PAN w Krakowie ${ }^{24}$.

Stanisław Małachowski (1736-1809) zasłynął jako marszałek Sejmu Czteroletniego z lat 1788-1792. W 1807 r. pełnił przez krótki czas funkcję prezesa Rady Ministrów Księstwa Warszawskiego. W tym samym roku został prezesem senatu. Sprawował również godność pierwszego wojewody Księstwa Warszawskiego ${ }^{25}$. Biesiadny anakreontyk K. Koźmiana dedykowany Małachowskiemu rozpoczyna się czołobitnym wersem: „Chlubo polskiego Senatu!”26.

$\mathrm{Z}$ tego samego okresu pochodzi Kantata na koronację Napoleona ${ }^{27}$, opublikowana w aneksie. Wiersz był drukowany pod tytułem Kantata na rocznice koronacji Napoleona ${ }^{28}$. Wynika to z faktu, że na początku grudnia $1810 \mathrm{r}$. utwór został wykonany w Warszawie na uroczystości upamiętniającej rocznicę koronacji cesarza. Po spektaklu opery Luigiego Cherubiniego Woziwoda paryski w Teatrze Narodowym artyści wnieśli na scenę transparent $\mathrm{z}$ wizerunkiem popiersia Napoleona. Chór zaśpiewał kantatę na cześć cesarza ze słowami

22 S. Kieniewicz, op. cit., s. 195-198.

23 Bibl. Nauk. PAU i PAN, rkps 2052, k. 150, 150v, 151, 151v, 152.

24 Zob. P. Żbikowski, Nieznane wiersze Kajetana Koźmiana..., s. 361-399.

25 Zob. m.in. Stanisław Małachowski. Marszałek Sejmu Czteroletniego, napisał E. Machalski, Poznań 1936, s. 40-136, 151-157.

${ }^{26}$ Bibl. Nauk. PAU i PAN, rkps 2052, k. 150. Zob. też P. Żbikowski, Nieznane wiersze Kajetana Koźmiana..., s. 381. P. Żbikowski, publikując ten wiersz, zakończył powyższy wers, rozpoczynający utwór, przecinkiem, a nie wykrzyknikiem. Za bardziej zasadne należy uznać zastosowanie wykrzyknika. Poeta użył w rękopisie tego znaku interpunkcyjnego, aby podkreślić swą cześć dla Małachowskiego.

27 Bibl. Nauk. PAU i PAN, rkps 2052, k. 154.

28 Zob. K. Koźmian, Kantata na rocznicę koronacji Napoleona, [w:] idem, Różne wiersze..., s. 65-66; idem, Kantata na rocznicę koronacji Napoleona, [w:] idem, Wybór poezji..., s. 34-35. 
K. Koźmiana. Pełny tekst wiersza przytoczono w sprawozdaniu prasowym z uroczystości. Autor publikacji prasowej podał pod utworem inicjały poety: „K.K.”29.

Tematykę filozoficzną ma wiersz Koźmiana Na filozofię Hegla. W autografie poeta podkreśla w tytule swój sędziwy wiek: Na filozofię Hegla - w r. 1848 życia $77^{30}$. Wydawcy wyborów poezji autora rezygnowali z podtytułu. $\mathrm{W}$ jednym wypadku edytor przeniósł informację o dacie powstania utworu i wieku poety do przypisu dolnego od tytułu ${ }^{31}$. W innym wydaniu redakcja całkiem zrezygnowała z podania wiadomości o wieku autora, umieszczając pod tekstem datę powstania wiersza -1848 r. ${ }^{32}$ Za najbardziej trafny trzeba uznać zabieg zastosowany przez poetę w autografie. K. Koźmian, zaznaczając w tytule swój wiek, wzmacnia polemikę z poglądami niemieckiego filozofa Georga Wilhelma Friedricha Hegla (1770-1831). Zarzuca filozofowi nadmierne hołdowanie racjonalizmowi. Uznaje za konieczny szacunek dla Boga jako „Stwórcy natury” i - szerzej - całego świata. Według Koźmiana człowiek winien się korzyć przed Stwórca. Poeta pisze o nieuniknioności ludzkiej śmierci, odwołując się do faktu zgonu filozofa ${ }^{33}$.

Charakter osobisty cechuje utwór Koźmiana dedykowany przyjacielowi poecie i dramatopisarzowi Franciszkowi Wężykowi (1785-1862). W rękopisie autorskim nosi on tytuł: Wiersz do Franciszka Wężyka jadqcego do wód do Karls$b a d u$. Pod tekstem autor umieścił informację nt. daty napisania utworu i swojego wieku: „W roku 1852 w 81 życia roku [u]” ${ }^{34}$. W wersji drukowanej z 1881 r. niesłusznie przeniesiono ją spod tekstu do tytułu: Do Franciszka Wężyka, jadacego do wód do Karlsbadu, w roku 1852, w 80 roku życia ${ }^{35}$. Z tak brzmiącego tytułu można błędnie wnioskować, że to Wężyk jechał do Karlsbadu w 1852 r. w wieku osiemdziesięciu lat. Koźmian życzy Wężykowi powrotu do zdrowia, aby stał się równie sprawny fizycznie, jak jest sprawny intelektualnie. Chwali twórczość dramatyczną adresata wypowiedzi poetyckiej. Przeciwstawia twórczość literacką swoją i Wężyka literaturze tworzonej przez młodsze pokolenia ${ }^{36}$. Przyjaźń

${ }_{29}$ Obchód uroczystości dnia 2 grudnia, „Gazeta Korespondenta Warszawskiego i Zagranicznego" 1810, nr 97, s. 1594-1595 (nr datowany: „Z Warszawy dnia 4 go grudnia 1810 we wtorek”).

${ }^{30}$ Bibl. Nauk. PAU i PAN, rkps 2052, k. 166v.

${ }^{31}$ K. Koźmian, Na filozofię Hegla, [w:] idem, Różne wiersze..., s. 121.

32 Idem, Na filozofię Hegla, [w:] idem, Wybór poezji..., s. 80-81.

${ }_{33}$ Zob. Bibl. Nauk. PAU i PAN, rkps 2052, k. 166v (rękopis autorski wiersza Na filozofię Hegla); K. Koźmian, Na filozofię Hegla, [w:] idem, Różne wiersze..., s. 121; idem, Na filozofię Hegla, [w:] idem, Wybór poezji..., s. 80-81.

${ }^{34}$ Bibl. Nauk. PAU i PAN, rkps 2052, k. 168.

${ }^{35}$ K. Koźmian, Do Franciszka Wężyka, jadacego do wód do Karlsbadu, w roku 1852, w 80 roku życia, [w:] idem, Wybór poezji..., s. [134]-135.

${ }^{36}$ Bibl. Nauk. PAU i PAN, rkps 2052, k. 168; K. Koźmian, Do Franciszka Wężyka..., s. [134]-135. 
między Koźmianem a Wężykiem zaowocowała dużym zbiorem korespondencji literackiej $^{37}$.

Utwory poetyckie Koźmiana to ważny dokument epoki, a także poglądów i mentalności autora. Koźmian utrwalał swe poglądy nacechowane koniunkturalizmem politycznym. Świadectwo mentalności poety stanowi wiersz na cześć hrabiego Wincentego Krasińskiego. Polityk chwali przyjaciela za rzekomą stałość poglądów oraz postawę patriotyczną. Współcześni czytelnicy znający historię Polski wiedzą, podobnie jak odbiorcy dziewiętnastowieczni, że Krasiński cechował się taką samą niekonsekwencją polityczno-ideową i równie dużym koniunkturalizmem jak Koźmian. Pochwalny utwór jest wyrazem nie ironii autora, ale jego zakłamania, względnie próbą uspokojenia własnego patriotycznego sumienia.

Okolicznościowym wierszom poety nie można odmówić także wartości literackiej, choć postklasyczny twórca nie dorównywał twórczością najwybitniejszym autorom okresu oświecenia ani wieszczom narodowym $\mathrm{z}$ doby romantyzmu.

\section{ANEKS}

Kantata na koronację Napoleona ${ }^{38}$

Dziś się do swego wzniósł przeznaczenia.

Geniusz zwycięstw i chwały.

Dziś wiernych Jemu ludów życzenia

Dzielił radością świat cały.

Jak z groźnym ${ }^{39}$ mieczem berło podnosi

Przedziały narodów gina,

Ziemia od jednej do drugiej osi

Braterską wszystkim krainą.

Północ przyjazne podaje dłonie,

Gasną zarzewia do boju,

W zburzonych falach Albion tonie,

A lud czci Dawcę pokoju.

${ }^{37}$ Zob. Korespondencja literacka Kajetana Koźmiana z Franciszkiem Wężykiem (1845-1856), zebrał, objaśnił i wstępem opatrzył S. Tomkowicz, w Krakowie 1913, passim (edycja książkowa korespondencji obu literatów, datowanej na okres 20 grudnia 1845 - 28 lutego 1856). Zob. też B. Czwornóg-Jadczak, Matuzalemowie klasycyzmu. W kręgu literackiej korespondencji Kajetana Koźmiana i Franciszka Wężyka, [w:] Od oświecenia do romantyzmu. Prace ofiarowane Piotrowi Żbikowskiemu, red. G. Ostasz, S. Uliasz, Rzeszów 1997, s. 52-62.

${ }^{38}$ Bibl. Nauk. PAU i PAN, rkps 2052, k. 154.

${ }^{39}$ W publikowanym rękopisie - błędna pisownia łączna (,zgroźnym”), poprawiona przy niniejszej edycji. 
Piękności! znamy ${ }^{40} \mathrm{w}$ nim dary twoje,

Uczuł twą władzę Bóg wojny

Dla Ciebie - Gruzy ${ }^{41}$ zburzyli Troi

przez $^{42}$ Ciebie dziś świat spokojny.

Pod Twoim godłem ukutej zgody,

Kto związek obrazi ścisły!

Którzyż mocarze? Które Narody?

Biada wam! harde ${ }^{43}$ zamysły.

Szczę́liwa ziemio, Szczęśliwy rodzie

Którego wdzięczne brzmią głosy, przy $^{44}$ każdym z tylu cudów obchodzie

Twe własne wystawiasz losy.

Usłysz że Wielki nasz Wskrzesicielu

Gdy ważąc przemiany świata,

W tak godnym Twojej wielkości celu

Zwraca myśl Twoję Sarmata.

Spójrz na pierwotne bytu zadatki

Na nadkruszone Kajdany ${ }^{45}$,

Dla Ciebie synów chowają matki.

Błagają niebo kapłani.

Tu gdy twe imię - ziomek wyrzecze,

Ogniem odwagi młódź pała,

Błyszczą do góry wzniesione miecze,

Żądzą ${ }^{46}$ bój, pogrom i chwała.

Władco! Narodów ${ }^{47}$ wyrok twój ${ }^{48}$ stanie

Świat się w zasadach zachwieje

Jednych rozdarte połkną otchłanie

Drugich spełnią się nadzieje. ${ }^{49}$

\section{K.K. [Kajetan Koźmian]}

${ }^{40} \mathrm{~W}$ rękopisie - taka pisownia - ,znamy” z małej litery.

${ }^{41}$ Taka pisownia („Gruzy” $\mathrm{z}$ dużej litery) - w rękopisie autorskim.

${ }^{42} \mathrm{~W}$ autorskim zapisie rękopiśmiennym - niekonsekwencja w pisowni - początek wersu z małej litery.

${ }^{43}$ W rękopisie Koźmiana - wyraz „harde” - z małej litery.

${ }^{44} \mathrm{~W}$ zapisie rękopiśmiennym - początek wersu z małej litery.

${ }^{45}$ W rękopisie poety - słowo „kajdany” - z dużej litery.

46 Pisownia niezgodna ze współczesnymi zasadami ortografii - ,rządzą” przez ,ż” zamiast przez ,rz".

${ }^{47}$ Pomyłka interpunkcyjna autora. Wykrzyknik powinien się znajdować, zgodnie z logiką tekstu i zasadami retoryki, po apostrofie „Władco Narodów”, a nie po jej pierwszym wyrazie.

${ }^{48}$ Niekonsekwencja w pisowni. Koźmian, zwracając się do cesarza w rękopisie wiersza, czasem używa czołobitnie dużej litery, a czasem małej.

${ }^{49} \mathrm{~W}$ ostatniej strofie wiersza - brak konsekwencji w interpunkcji w porównaniu z poprzednimi zwrotkami. Poeta nie wprowadził żadnych znaków interpunkcyjnych między wersami. 


\section{MANUSCRIPTS OF KAJETAN KOŹMIAN'S POETRY \\ IN THE ACADEMIC LIBRARY OF THE POLISH ACADEMY OF ART AND SCIENCES AND THE POLISH ACADEMY OF SCIENCES COLLECTION}

Keywords: Koźmian Kajetan (1771-1856), authorial manuscripts of poetry, the Academic Library of the Polish Academy of Art and Sciences and the Polish Academy of Sciences manuscripts

\section{SUMMARY}

The Academic Library of the Polish Academy of Art and Sciences and the Polish Academy of Sciences collection contains a great number of works by a poet Kajetan Koźmian (1771-1856). Especially valuable are the authorial manuscripts of the writer's works.

The paper deals with some chosen autographs of K. Koźmian's poems available in the Academic Library of the Polish Academy of Art and Sciences and the Polish Academy of Sciences. An annex has been added at the end - a publication of K. Koźmian's poem Cantata for the Coronation of Napoleon after the author's manuscript which has yet to become a subject of any academic research.

The paper discusses the following authorial manuscripts of K. Koźmian's poems with some elements of analysis: To Zygmunt Krasiński (Poem I), To Wincent Krasiński in 1843, An Anacreontic to S. Małachowski, Cantata for the Coronation of Napoleon, On Hegel's Philosophy in 1848, 77 years of age, A Poem to Franciszek Węzyk on the Road to Karlsbad spa.

The paper refers to a research on some manuscripts of K. Koźmian's poems done by a literary historian Piotr Żbikowski (1935-2011).

АДРИАН УЛЬЯШ

\section{РУКОПИСИ СТИХОВ КАЭТАНА КОЗЬМЯНА В СОБРАНИЯХ НАУЧНОЙ БИБЛИОТЕКИ ПОЛЬСКОЙ АКАДЕМИИ ЗНАНИЙ И ПОЛЬСКОЙ АКАДЕМИИ НАУК В КРАКОВЕ}

Ключевые слова: Козьмян Каэтан (1771-1856), Козьмян Каэтан (1771-1856) рукописи авторской поэзии, Научная библиотека Польской академии знаний и Польской академии наук в Кракове рукописи

\section{АННОТАЦИЯ}

В собраниях Научной библиотеки Польской академии знаний и Польской академии наук в Кракове хранится богатое наследие поэта Каэтана Козьмяна (1771-1856). Особую ценность представляют рукописные авторские записи произведений поэта. Статья посвящена избранным автографам поэзии К. Козьмяна, доступным в Научной библиотеке Польской академии знаний и Польской академии наук. 
В приложении - публикация стихотворения К. Козьмяна Kantata na koronacje Napoleona (Кантата на коронацию Наполеона), в соответствии с рукописью автора. Это произведение до сих пор не было предметом научной публикации.

В статье рассмотрены, с использованием элементов анализа, авторские рукописи стихов К. Козьмяна Do Zygmunta Krasińskiego (wiersz I), Do Wincentego Krasińskiego $w$ roku 1843, Anakreontyk do S. Małachowskiego, Kantata na koronacje Napoleona, Na filozofię Hegla - wr. 1848 życia 77, Wiersz do Franciszka Wężyka jadacego do wód do Karlsbadu.

Упомянуты исследования историка литературы Петра Жбиковского (1935-2011) над частью рукописей стихов К. Козьмяна. 